\title{
Integrating Facebook as a Web 2.0 Tool in a Responsive Pedagogy for Multimodal Oral Presentation Skills
}

\author{
Lee Sze Seau ${ }^{a}$ \\ leess@ucsiuniversity.edu.my \\ UCSI University, Kuala Lumpur, Malaysia \\ Hazita Azman \\ hazita@ukm.edu.my \\ Universiti Kebangsaan Malaysia, Malaysia
}

\begin{abstract}
Technology both complicates and liberates oral presentation pedagogy in higher education. On one hand, 21 st century communication realities require students to deliver multimodal oral presentations but educators have only begun to experiment with the relevant pedagogy. On the other hand, Web 2.0 offers vast pedagogical potential which practitioners have just begun to explore. Confronted by a pedagogical predicament and intrigued by the affordances of Web 2.0, we designed the Responsive Multimodal Oral Presentation Pedagogy (RMO2P) to enhance the learning of multimodal oral presentation skills among EAP (English for Academic Purposes) students. RMO2P integrated Facebook as a Web 2.0 tool with videos, collaborative learning and feedback. A teacher-researcher implemented RMO2P in a public speaking class of 20 EAP students for a semester. Thematic analysis of multiple sources of data which included student artifacts, observational data and inquiry data contributed to the findings. The findings indicated that Facebook was a feasible Web 2.0 tool that can be effectively integrated with other pedagogical techniques. As a result, the participants demonstrated enhanced conceptual knowledge and heightened self-awareness as presenters of multimodal oral presentations. Since Facebook was integrated as a Web 2.0 tool in a responsive method for multimodal oral presentation skills to overcome situational constraints including inadequate learning management systems (LMS), stakeholders who are seeking alternative methods to enhance the teaching of oral presentation skills may adapt the intervention to enhance learning outcomes.
\end{abstract}

Keywords: Facebook; multimodal oral presentation skills; pedagogy; higher education; Web 2.0

\section{INTRODUCTION}

Apart from conventional trials in delivering oral presentations such as the anxiety of speaking in front of the public and their English ability, students also face challenges which are compounded by how technology has changed delivery of oral presentations. The significant shift to a more semiotic style in academic oral presentations due to technological developments has long been acknowledged (Kress, 2010; O'Halloran et al., 2016). New technologies have made meaning-making "increasingly multimodal - in which written-linguistic modes of meaning interface with oral, visual, audio, gestural, tactile and spatial patterns of meaning" (Cope \& Kalantzis, 2015, p. 3). The design of presentation slides, for example, is one aspect where students have to engage multimodal literacies, although classroom teaching has not effectively taught them how to do so (Hung et al., 2013).

${ }^{a}$ Main \& corresponding author 
The crux of the problem which warrants research attention is the need to develop effective instructional approaches to address the learning of multimodal skills required of oral presentations. Adopting a multimodal approach to view oral presentations underlines that students now would need to orchestrate a range of semiotic modes in a single presentation, such as written language, media (audio, animation and/or video), pictures, gestures, speech, whereby the presentation is frequently enhanced by technology (Anstey \& Bull, 2018; Kress, 2010; Mills, 2016). This understanding of multimodality in oral presentations mirrors the observation that digital multimodal composing requires the management of multiple semiotic resources (Reyna et al., 2018; Unsworth \& Mills, 2020).

Having a pedagogical approach that views speech as multimodal, whereby multiple modes are orchestrated to express meaning, requires further development (Barrett \& Liu, 2016; Camiciottoli \& Campoy-Cubillo, 2018). Although the updated Common European Framework of Reference for languages: Language, Teaching, Assessment (Council of Europe, 2018) has acknowledged the existence of various modes beyond the linguistic mode in meaning-making, exploring and developing pedagogical approaches that address multimodality requires investment from educators (Camiciottoli \& Campoy-Cubillo, 2018; Lim et al., 2021; Mills, 2016). In fact, even the development of pedagogical approaches for oral presentation competence in general requires more research attention (Tsang, 2020; Van Ginkel et al., 2015), whereby oral presentation competence could be understood as: "the combination of knowledge, skills, and attitudes needed to speak in public in order to inform, self-express, to relate and to persuade" (De Grez, 2009, p. 5). Despite being effective in developing a multimedia-based instructional approach for oral presentations, researchers encouraged teachers to experiment with alternative approaches which experiment with different theories and instructional designs (De Grez et al., 2009). There is also suggestion for teachers to attempt pedagogical experimentations by combining various techniques such as peer feedback and modeling differently according to clear design principles (Van Ginkel et al., 2015). In terms of systematically guiding the development of multimodal oral presentation skills, more practice and opportunities need to be provided for students to evaluate their non-verbal skills so that they can develop into more confident speakers (Camiciottoli \& Campoy-Cubillo, 2018; Hung et al., 2013; O’Halloran et al., 2016).

While there are definite challenges posed by transformations of communication technologies to oral presentation pedagogy, we recognise that technology also offers extensive pedagogical potential, and are interested in drawing from Web 2.0's affordances to enhance oral presentation pedagogy. Chawinga (2017), for instance, recommends for Web 2.0 to be utilised for formal learning, whereby Web 2.0 is viewed as a technological foundation that hosts social media applications such as Facebook and Twitter, which support user-generated content. In addition, a review of the learning of foreign languages concluded that social networking available through Web 2.0 enables peer-to-peer communication and collaboration, interaction in the target language and supports both asynchronous and synchronous communication (Golonka et al., 2014). We posit that the affordances of Web 2.0 for language pedagogy could have direct implications on oral presentation pedagogy. In pedagogical explorations of Web 2.0 for the development of oral skills, the following aspects are some of the areas that may benefit from engaging Web 2.0 for formal learning:

- communication and collaboration which are conducive for the development of oral presentation skills (Magogwe et al., 2015);

- $\quad$ speaking skills among low-proficiency ESL learners (Nadzrah et al., 2013);

- $\quad$ speaking fluency and confidence (Huang, 2015; Sun \& Yang, 2015). 
Given varied possibilities of learning gains from a free and relatively consistent resource, we are motivated to engage Web 2.0 to support the learning of multimodal oral presentation skills.

In brief, as EAP teachers who were both confronted by the need to explore effective pedagogies for multimodal oral presentation skills and motivated by the potentials of Web 2.0, we designed an intervention that could be applied in a tertiary classroom within one semester. Named the Responsive Multimodal Oral Presentation Pedagogy (RMO2P), we integrated Facebook as a Web 2.0 tool with videos, collaborative learning and feedback. The term responsive connotes that as teacher-researchers, we possess the initiative and attitude to respond proactively to practical challenges and limited resources. The limited resources include inefficient learning management system (LMS) in our institution which is troubled in the aspects of file size allowance, interactive features and accessibility (more elaboration in the next section). This paper hence aims to explore the viability of integrating Facebook with other pedagogical techniques in RMO2P to target multimodal oral presentation skills in an EAP class.

\section{LITERATURE REVIEW}

\section{THE IMPACT OF WEB 2.0 ON ORAL SKILLS}

Since empirical studies which linked Facebook to the development of oral skills are limited (Barrot, 2018), we extended the literature review to consider the impact of various types of Web 2.0 tools on manifestations of oral skills apart from oral presentation skills. The Web 2.0 tools that have thus far been investigated for the development of various types of oral skills, which ranged from oral discussions to the more formal oral presentation skills, are voice blogging (Huang, 2015), video blogging (Shih, 2010), asynchronous online discussions (Nadzrah et al., 2013) and Facebook (Magogwe et al., 2015; Sun \& Yang, 2015). The focus of our literature review involved a range of English learning environments, such as ESL (English as second language), EFL (English as foreign language) and EAP (English for academic purposes), but the participants were all students at the tertiary level, which is the similar education level to the participants in this study.

There were indeed many encouraging benefits of Web 2.0 for the development of oral skills. Facebook and YouTube could develop public speaking skills and confidence (Sun \& Yang, 2015). Video blogging improved public speaking skills such as grammar, pronunciation, gestures, facial expressions and eye contact (Shih, 2010). Students had positive perceptions of another Web 2.0 tool, voice blogging, for speaking skills in terms of fluency, pronunciation, expression and confidence (Huang, 2015). In addition, students could develop awareness of correct linguistic features and low-proficiency students could develop confidence through asynchronous online discussion (Nadzrah et al., 2013). Furthermore, collaboration that builds confidence, notably for students with low self-esteem, could be achieved through engaging Facebook for the learning of oral presentation skills (Magogwe et al., 2015). Moreover, feedback and reflection consistently available through Web 2.0 could lead to enhanced oral performance (Barrett \& Liu, 2016). Although these studies did not focus on multimodal oral presentation skills, we were interested to explore if the reported affordances could contribute to the development of components of multimodal skills such as oral ability and gestural ability.

In terms of risks, there are certain challenges that any intervention involving Web 2.0 would need to be prepared for. Students could be troubled with anxiety of posting online (Shih, 2013) and be unwilling to engage in Web 2.0 as a formal learning environment (Kabilan et al., 2010). The risks of being troubled by technical issues (Nadzrah et al., 2013), privacy issues (Sun \& Yang, 2015) and time management (Shih, 2010) may be more prevalent than 
conventional approaches. Participation could be uneven (Azru, 2014) although Web 2.0 is essentially a democratic platform. For instance, students could be unwilling to participate and need to be monitored (Nadzrah et al., 2013). With these issues in mind, we adopted the suggestions that teachers need to provide constant and consistent guidelines and strategise the integration of Web 2.0 tools with other aspects of classroom learning (Huang, 2015).

\section{RATIONALE FOR SELECTING FACEBOOK}

We selected Facebook as the Web 2.0 tool in the intervention due to its accessibility, social networking features and multimodal affordances. Facebook has a statistically validated popularity in Malaysia with 25 million users (Statista, 2021) and Asia-Pacific (Barrot, 2018), which is expected to continue to grow. In the Asian higher education context, Facebook has been explored as a plausible learning management system (LMS) (e.g. Kabilan et al., 2010; Naghdipour, 2017; Shih, 2013). A critical review of studies on Facebook as a learning environment for language teaching and learning concludes this: "Facebook is a dynamic and flexible tool that permits productive language activities and is readily adaptable to changing contexts" (Barrot, 2018, p. 9). The implication is that Facebook could support technologicallyenhanced contexts for the learning of productive skills such as writing and speaking.

Another reason for selecting Facebook is its inherent social networking features that could be explored for developing oral skills. Magogwe et al. $(2015$, p. 4) stated that "Facebook provides social networking services like the inbox, wall/timeline, newsfeed, notifications and numerous other add-in functions like events, photos, notes, etc". We also contend that the inherent design of Facebook allows multiple modes of meaning-making such as the visual, audio and written-linguistic modes to interface intricately with each other. As a result, Facebook could offer multimodal affordances which could encourage peer collaboration and active meaning-making.

Critical reviews of existing literature have indicated a lack of empirical studies that examine Facebook for teaching and learning oral skills (Barrot, 2018; Manca \& Ranieri, 2016). In addition, practitioners who have the efficient support of a technical team and sophisticated LMS may find the proposal of selecting Facebook as a Web 2.0 tool unappealing or even naive. However, given the reality of budget cuts in higher education (Abusalim et al., 2020; Li, 2017) which directly affects the quality of LMS systems implemented in higher education institutions, we find the freely available multimodal affordances and accessibility of Facebook pedagogically appealing. In Botswana, where internet access is frequently limited, Facebook can be used to complement other LMS since it is cheaper and more accessible (Magogwe et al., 2015). In Malaysian higher education, a survey among undergraduates indicated that the students were optimistic that Facebook could facilitate English learning in terms of communication skills, confidence and motivation, in addition to several other benefits (Kabilan et al., 2010). There were also reports on Facebook reducing writing anxiety (Ponnudurai \& Jacob, 2014) and supporting team-based learning for language learning (Rasiah, 2014), but the teacher must provide clear and consistent guidelines when supporting formal learning with Facebook (Adi Kasuma, 2017). Moreover, as EAP practitioners who have more than a decade of experience, we find that the LMS system operating in our context has these practical limitations: constraining in terms of file size allowance, limited in interactivity and unreliable in accessibility. Each student is only allowed a file size of 50MB per post, which is too limited when students want to share multimodal compositions which involve video and audio modalities. Students are also reluctant to use the chat features and frequently face problems logging onto the system. A profiling questionnaire (Appendix A) confirmed that the students agree with us and are: 1) frequent users of Web 2.0 who $\log$ on to Facebook daily and 2) agreeable to exploring Facebook for formal learning (refer to Table 1). 


\section{METHODOLOGY}

To examine the viability of integrating Facebook as a Web 2.0 tool with other pedagogical techniques in an intervention for multimodal oral presentation skills (RMO2P), we triangulated three types of qualitative data, which included artifacts in the form of Facebook tasks, observational data in the form of reflection diary and inquiry data in the form of focus group interviews. Triangulation of different qualitative data sources helps to achieve credibility of findings through discovering overall consistency and explanations for divergent interpretations (Patton, 2015).

\section{CONTEXT OF STUDY AND PARTICIPANTS}

We developed and evaluated the intervention in a Public Speaking course which was one of the EAP courses conducted by the English department in a Malaysian university college. The weekly contact time was 2.5 hours and the course ran for 13 weeks each semester excluding exam and revision weeks. The main learning outcome was to collaboratively develop and deliver multimodal oral presentations. For our pedagogical and research purposes, we have identified ten components which could operationalise multimodal oral presentation skills through document analysis and expert validation. The ten components were introduction, content, organisation, conclusion, linguistic ability, oral ability, visual design ability, gestural ability, overall credibility and coordination.

The 20 student participants ( 2 males and 18 females) were from a Degree in Media Studies class. The profiling questionnaire indicated that the participants were between 19 and 22 years old, and were mostly trilingual in Mandarin, Malay and English, besides speaking one or more Chinese dialects (Appendix A). Their abilities in the English language were heterogeneous based on their grades in the national Malaysian examination for secondary school students (SPM). Three students attained A and A- respectively, five students achieved $\mathrm{B}+$ and $\mathrm{B}$ respectively, one student achieved $\mathrm{C}+, 2$ students scored $\mathrm{C}$ and one student received D. Table 1 depicts the profile of the students based on the profiling questionnaire which also highlights the students' frequent Facebook usage and perception of engaging Facebook for formal learning.

TABLE 1. Profile of student participants

\begin{tabular}{ccccc}
\hline $\begin{array}{c}\text { Names of students } \\
\text { (pseudonym) }\end{array}$ & Year of birth & SPM English grade & $\begin{array}{c}\text { Log on to } \\
\text { Facebook daily }\end{array}$ & $\begin{array}{c}\text { Agree to using } \\
\text { Facebook for } \\
\text { formal learning }\end{array}$ \\
\hline Mei & 1993 & A- & Yes & Yes \\
Choo & 1992 & B & Yes & Yes \\
Isaac & 1992 & B & Yes & Yes \\
Minnie & 1993 & A & Yes & Yes \\
Cindy & 1993 & B & Yes & Yes \\
Yvette & 1993 & A & Yes & Yes \\
Hui & 1993 & A- & Yes & Yes \\
Timmy & 1993 & B & Yes & Yes \\
Ketam & 1993 & C & Yes & Yes \\
Dee & 1992 & A- & Yes & Yes \\
Carrie & 1993 & A & Yes & Yes \\
Ang & 1991 & B & Yes & Yes \\
Ying & 1994 & D & Yes & Yes \\
Katherine & 1992 & B & Yes & Yes
\end{tabular}




\begin{tabular}{ccccc} 
Ting & 1993 & B + & Yes & Yes \\
Kai & 1994 & C & Yes & Yes \\
Gan & 1994 & B & Yes & Yes \\
\hline
\end{tabular}

One of us played the role of the teacher-researcher by developing the intervention based on the problems observed through daily teaching. These problems include speaking anxiety, lack of engaging materials and lack of attention to the multimodal skills required in presentations in the existing course designs. It is through teaching oral presentation courses for 15 years in the EAP context that the teacher-researcher has become immersed in the affordances and challenges of technology for oral presentation pedagogy. Furthermore, the teacher-researcher conducted the interviews, in addition to designing, implementing and monitoring the Facebook tasks which were part of the intervention.

\section{INTEGRATING FACEBOOK WITH OTHER TECHNIQUES IN THE INTERVENTION (RMO2P)}

RMO2P involved integrating Facebook with theoretically-supported techniques which were available to us and agreeable to our student participants based on a profiling questionnaire. We integrated Facebook with two types of videos, which were TED (Technology, Education and Design) videos (Hayward, 2017) and self-recorded videos of student presentations (De Grez et al., 2009). The participants worked in self-selected groups of four when collaborative learning was involved (Nguyen, 2013). The teacher-researcher provided individualised feedback for every task (Van Ginkel et al., 2017). We set up and managed a closed and private Facebook group to conduct both synchronous and asynchronous chats, and assign tasks that aimed to support the learning of multimodal oral presentation skills (Table 2).

All the Facebook tasks reinforced and extended what the participants had learned in the conventional classroom. The participants were assigned a total of four individual tasks and two collaborative tasks which targeted different aspects of multimodal oral presentation skills. The total number of six tasks could be scheduled strategically within 13 weeks of a complete semester while the mixture of collaborative tasks and individual tasks provided opportunities for students to demonstrate their individual abilities and collaborative synergies. There were more individual Facebook tasks to balance the class activities which were mostly collaborative. Excerpts of the tasks could be sampled in Appendices D and E.

TABLE 2. The integration of Facebook with other techniques in RMO2P

\begin{tabular}{|c|c|c|c|c|}
\hline Week & $\begin{array}{l}\text { Description of task on } \\
\text { Facebook }\end{array}$ & $\begin{array}{l}\text { Integrated } \\
\text { techniques }\end{array}$ & $\begin{array}{l}\text { Targeted aspect of } \\
\text { multimodal oral } \\
\text { presentation skills }\end{array}$ & Type of task \\
\hline 2 & $\begin{array}{l}\text { Task 1: Each participant } \\
\text { analysed own performance } \\
\text { after viewing video recording } \\
\text { of first group presentation. }\end{array}$ & $\begin{array}{l}\text { Self-recorded } \\
\text { video; } \\
\text { feedback; } \\
\text { Web } 2.0\end{array}$ & $\begin{array}{l}\text { Critical awareness of } \\
\text { own multimodal oral } \\
\text { presentation skills }\end{array}$ & Individual \\
\hline 3 & $\begin{array}{l}\text { Task 2: Participants developed } \\
\text { an oral analysis of a TED } \\
\text { presentation assigned by the } \\
\text { teacher. The teacher monitored } \\
\text { discussions on Facebook but } \\
\text { they delivered their oral } \\
\text { analysis in class as their second } \\
\text { group presentation in Week } 7 \text {. }\end{array}$ & $\begin{array}{l}\text { TED video; } \\
\text { collaborative } \\
\text { learning; } \\
\text { feedback; } \\
\text { Web } 2.0\end{array}$ & $\begin{array}{lr}\text { Knowledge } & \text { and } \\
\text { awareness of required } \\
\text { multimodal } & \text { oral } \\
\text { presentation skills } & \end{array}$ & $\begin{array}{l}\text { Small group } \\
\text { collaboration }\end{array}$ \\
\hline 5 & $\begin{array}{l}\text { Task 3: Each collaborative } \\
\text { group posted an improved } \\
\text { PowerPoint slide that had been } \\
\text { previously designed for the }\end{array}$ & $\begin{array}{l}\text { Collaborative } \\
\text { learning; } \\
\text { feedback; } \\
\text { Web } 2.0\end{array}$ & $\begin{array}{l}\text { Knowledge and ability } \\
\text { in visual design }\end{array}$ & $\begin{array}{l}\text { Small group } \\
\text { collaboration }\end{array}$ \\
\hline
\end{tabular}




\begin{tabular}{|c|c|c|c|}
\hline & $\begin{array}{l}\text { first group presentation and } \\
\text { explained the rationale for the } \\
\text { changes. }\end{array}$ & & \\
\hline 6 & $\begin{array}{l}\text { Task 4: Each participant } \\
\text { analysed the visual design of a } \\
\text { self-selected PowerPoint slide. }\end{array}$ & $\begin{array}{l}\text { Feedback; } \\
\text { Web } 2.0\end{array}$ & $\begin{array}{l}\text { Analysis of visual Individual } \\
\text { design }\end{array}$ \\
\hline 7 to 12 & $\begin{array}{l}\text { Task 5: Each participant shared } \\
\text { a TED video and posted an } \\
\text { analysis. }\end{array}$ & $\begin{array}{l}\text { TED video; } \\
\text { feedback; } \\
\text { Web } 2.0\end{array}$ & $\begin{array}{lrr}\text { Knowledge } & \text { and } & \text { Individual } \\
\text { awareness of required } & \\
\text { multimodal } & \text { oral } \\
\text { presentation skills } & & \\
\end{array}$ \\
\hline 13 & $\begin{array}{l}\text { Task 6: Each participant } \\
\text { commented on the } \\
\text { performances of the most } \\
\text { outstanding or most improved } \\
\text { peers in the final presentation. }\end{array}$ & $\begin{array}{l}\text { Self-recorded } \\
\text { video; } \\
\text { feedback; } \\
\text { Web } 2.0\end{array}$ & $\begin{array}{l}\text { Critical awareness of Individual } \\
\text { peers' multimodal oral } \\
\text { presentation skills }\end{array}$ \\
\hline
\end{tabular}

\section{DATA COLLECTION AND ANALYSIS}

To infer the findings, we triangulated three sources of qualitative data, which included artifact, observational data and inquiry data.

Facebook Tasks (Artifact). We agree that since Facebook allows students to post their own views, self-assess and comment on others' postings (Magogwe et al., 2015), the tasks that participants complete through Facebook serve as a type of student-generated artifact that could be indicative of their perceptions (Hendricks, 2017). As a form of student-generated artifact, the Facebook tasks could assist in identifying learning problems, stimulate ideas for improving teaching strategies and observe long-term changes in skill development and thinking (Henning et al., 2009). Although the student participants were primary contributors, the teacherresearcher's consistent feedback on this platform was included for data analysis. The feedback which could play functions such as praising, suggesting, and probing would be elaborated in the discussion of findings. The Facebook group was set as private to protect online privacy (Sun \& Yang, 2015). Pseudonyms were created for the participants, in addition to removing or editing information that may expose their identities. Excerpts of the tasks are in Appendices D and $\mathrm{E}$.

Reflection Diary with Field Notes (Observational Data). Field notes, as a kind of observational data, are detailed information of implementation, participant behaviour and surprising events (Hendricks, 2017). It may provide the emic (insider) perspective on issues (Patton, 2015). The teacher-researcher who served as the participant-observer wrote field notes on multiple observations of 13 lessons of 2.5 hours each (32.5 hours in total). We refer to our observational data as reflection diary instead of field notes because the data contain evaluation of each lesson and proposed modifications which were guided by the act-evaluate-modify processes of the action-reflection cycle (McNiff \& Whitehead, 2011). Appendix B presents a sample of the observational data we collected through writing reflection diary with field notes.

Focus Group Interviews (Inquiry Data). As a type of inquiry data, interviews lend insight into participants' perceptions about the effectiveness of an intervention in terms of its positive and negative characteristics, and suggestions for improvement (Hendricks, 2017). The 20 student participants played the role of respondents, where they "speak primarily of and for themselves - about their own motivations, experiences and behaviors" (Tracy, 2013, p. 141). The teacher-researcher conducted focus group interviews at the end of the pedagogical intervention. A list of open-ended questions guided the conduct of the interviews, and there was a list of possible probes to consider if the participants required prompting (Appendix C). We grouped the participants in the same collaborative groups of four that they worked with in class to put them at ease. We utilised Facebook messenger to conduct the interviews because online platforms address the issues of costs, location and time (Marshall \& Rossman, 2011). 


\section{DATA ANALYSIS}

Thematic analysis, perceived as a method to identify, analyse, organise, describe, and report themes (Braun \& Clarke, 2006), was conducted on all sets of qualitative data. First, we organised the data by data source and chronologically (Tracy, 2013). Then, template strategies were used to make "direct transfer" of the various sources of data into separate "predeveloped data-recording charts" (Marshall \& Rossman, 2011, p. 211). Figure 1 shows a snapshot of the data from the Facebook tasks being organised with template strategies.

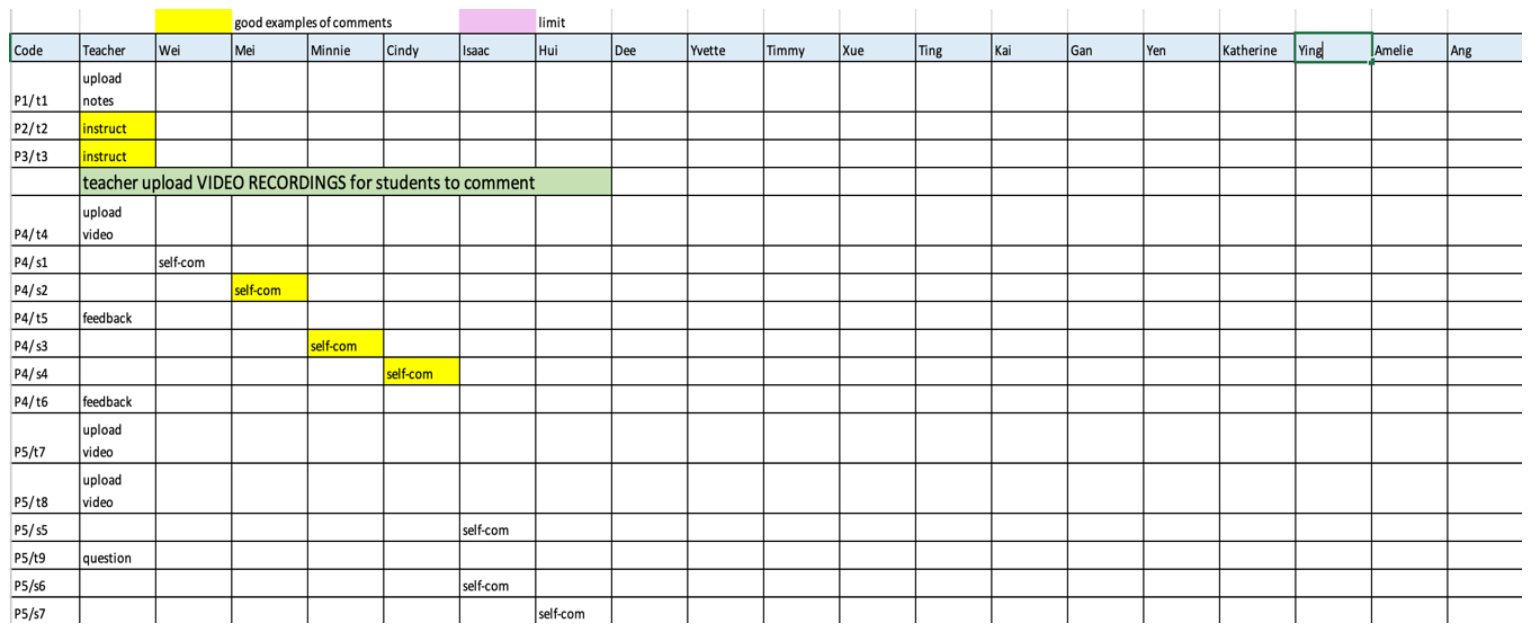

FIGURE 1. Example of template strategy used on Facebook data

The qualitative data from all sources were analysed through two cycles of coding. We conducted primary-cycle coding that can be defined as "initial coding activities that occur more than just a single 'first' time. The data might be read and coded several times during this primary stage" (Tracy, 2013, p. 189). In this cycle, we engaged descriptive coding and in vivo coding. Descriptive coding identifies the topic of the selected data and is frequently used to code field notes and artifacts (Saldaña, 2016). Descriptive coding involves employing iterative analysis within each source of data which "alternates between emic, or emergent, readings of the data and an etic use of existing models, explanations, and theories" (Tracy, 2013, p. 184). The following list were some codes we inferred through the etic reading during the iterative analysis:

- confidence

- grammar

- pronunciation

- grammar

- fluency

- $\quad$ self-esteem
- feedback

- oral ability

- gestural ability

- privacy issues

- technical issues

- time management

In vivo codes "use the language and terms of the participants themselves" (Strauss, 1987, cited in Tracy 2013, p. 190). In vivo coding encourages familiarisation with participant's views in interview transcripts and decisions on whether the data is salient enough to be coded is based on the instincts of the researcher (Saldaña, 2016). In this study, the in vivo codes were mostly based on the verbatim expressions which the participants used to describe their learning experiences. Some of the codes which were contributed by in vivo coding were convenience, good idea, own space to discuss, inform and interesting. 
Following primary-cycle coding, we engaged second-cycle coding by attempting to "organize, synthesize, and categorize them into interpretive concepts" (Tracy, 2013, p. 194). Second-cycle coding involves "interpretation and identifying patterns, rules, or cause-effect progressions" (ibid.). In this level, we mostly engaged pattern coding which is appropriate for searching for explanations and developing major themes (Saldaña, 2016). Figure 2 illustrates the coding process in a diagram.
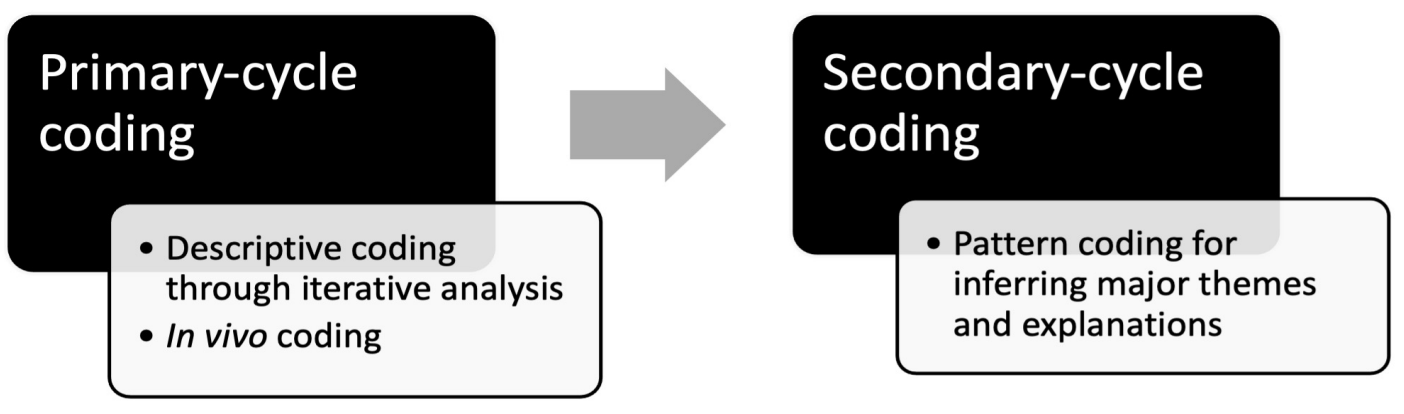

FIGURE 2. Coding process

\section{DISCUSSION OF FINDINGS}

The findings indicated that it was viable to integrate Facebook with the other pedagogical techniques in an intervention which targets multimodal oral presentation skills because of these two features: 1) Facebook functioned as a feasible Web 2.0 tool that supported learning, and 2) Facebook complemented and extended the impact of the other techniques in the intervention. In terms of the impact on the learning of multimodal oral presentation skills, the participants improved their conceptual knowledge about multimodal oral presentations and their selfawareness as presenters. Throughout the discussion, we use pseudonyms to refer to the participants to protect their privacy, and we maintain their grammatical and expression errors to convey their authentic voice.

\section{FEASIBLE WEB 2.0 TOOL}

Facebook emerged as a feasible tool that was supportive of learning due to affordances such as convenience and comfort. The reflection diary recorded the commitment required of the participants was to: 1) log on once a week to check for updates and read comments, and 2) complete four tasks individually and another two tasks in their collaborative groups (Table 2). In response to this, 'convenience' reverberated as the reason why the participants approved of learning through Facebook. Yee elaborated that Facebook was a 'good idea' for the management of assigned tasks.

The reflection diary cited observations of participants being highly engaged and comfortable with using Facebook which was an accessible tool because its 24-hour availability encouraged independent learning. Setting the Facebook group as private may have also heightened the level of security and comfort since participants confessed to have enjoyed 'own space to discuss' and felt 'not so awkward'. The depth of familiarity enabled them to express their critical thoughts through the given tasks, one of which was Task 5 (Table 2). The following quote reflects Ting's critical thinking when she analysed the multimodal abilities of a TED presenter named Oefner:

At the beginning of the talk, presenter had used some pictures to engage the audience's attention, and all the pictures are colourful and it make me feel impressive [sic]. Demonstrations make the whole presentation become more lively and let the audiences have a better understanding about 
the relationship between art and science... On the other hand, I think the presenter had not make enough eye contact with the audiences and he's look like thinking about something when he deliver his presentation [sic].

Cindy admitted that the comfort of use encouraged her to muster the courage to write comments in formal English although she may expose her linguistic weakness because of the familiar audience and the consistent teacher support she received through this platform. This is a different motivation for writing in English as compared to the survey by Kabilan et al. (2010) which cited an English speaking audience as the motivator. Similar to Ting, she was able to evaluate a TED speaker critically for Task 5 (Table 2):

\begin{abstract}
In my opinion, I like his speech very much and I think he's perfect! But there is one suggestion I would like to give which is, he could give the candy to audience earlier, not at the end of his speech. This maybe will make audience more attractive his speech [sic].
\end{abstract}

Student analyses of expert presentations which were exemplified by Ting and Cindy expressed evaluations with constructive suggestions, which reflected confident grasp of knowledge in what constituted effective multimodal oral presentation skills. The students' expressive involvement in the assigned tasks reinforced Cope and Kalantzis's (2015) suggestion that multimodal tasks could enhance student engagement. The tasks in the intervention (Table 2) appealed to more modalities such as visual and audio compared to the written-linguistic mode that is frequently featured in traditional classrooms. Furthermore, contrary to the suggestion that inhibition could result from engaging Facebook for formal learning (Sun \& Yang, 2015), the levels of engagement the participants demonstrated show convincing support for the viability of Facebook as a Web 2.0 tool.

\title{
CONDUCIVE FOR MODELS, EXPRESSIONS OF VIEWS AND INTERESTS
}

While past studies recommended supplementing learning through Web 2.0 with videos (Shih, 2010), the findings illustrated how Facebook extended the range of model presentations and provided more opportunities for participants to express their views.

The interview responses insightfully indicated how Facebook supported the learning of multimodal oral presentation skills through videos, both in the forms of self-recorded videos and TED videos. Participants expressed that peer-shared TED videos drew attention to the model presentations that they probably would have missed on their own.

Dee admitted that she had developed knowledge through sharing videos and making comments about them on Facebook. When analysed closely, Dee's analysis of a TED presentation (Task 5, Table 2) reflected insights that could only result from an improved grasp of conceptual knowledge. The following excerpt demonstrates that despite being weak in linguistic proficiency, Dee successfully analysed the presenter's specific purpose, intended audience and supporting materials:

\footnotetext{
This is not a talk to persuade or inform something, only to express and share about the presenter's gained knowledge. I think this topic is not suitable for all people only suitable to some people who are interesting with nature and photograph. She shows the suitable material, that is the photo of storm, and it is very attracting photo, is a good visuals to explain the storm [sic].
}

Notes in the reflection diary about Task 5 (Table 2) pointed out that sharing and analysing TED videos validated a wide range of interests among the participants. The validated interests included fields such as philosophy, technological innovations, nature, art and design, music, education and religion. The teacher-researcher reflected that, 'As a teacher, I never would have selected topics such as philosophy, Nature and religion at the risk of appearing too 
pedantic'. We posit that this validation would not have been achieved without the social networking affordances (Golonka et al., 2014) and inherent multimodal features of Facebook which supported video sharing and posting of comments (refer to excerpt in Appendix D).

\section{ENABLED PEER SHARING AND PEER SUPPORT}

Various Web 2.0 tools such as video blogging (Shih, 2010) and asynchronous online discussion (Nadzrah et al., 2013) have been reported to support collaboration that is required for oral presentation preparations. Continuing the line of research on peer collaboration, this study empirically illustrated how Facebook could support collaborative learning by encouraging peer sharing online and providing opportunities to mutually acknowledge each other's development when there is purposefully and meaningfully designed learning tasks.

A consistent pattern that surfaced from the interviews indicated that the participants generally agreed that they had learned from peer sharing which the Facebook tasks allowed and encouraged. For instance, Tasks 1, 3, 4 and 5 (Table 2) provided the participants with opportunities to learn from peers through reflecting on what the peers had posted on the multimodal abilities of presenters and the visual design of PowerPoint slides. The participants also highlighted that the meaningful opportunity to comment on every reflection or post was also crucial to their learning because the opportunties raised their self-awareness and they could offer suggestions to their peers. Therefore, the findings reinforced suggestions by previous studies that there should be appropriately designed learning tasks which align with lesson objectives (Chawinga, 2017) and creation of meaningful experiences (Kabilan et al., 2010).

For Task 6 (Table 2), the teacher-researcher requested each participant to emphasise a positive aspect of any peer's performance, for instance by mentioning a peer who showed the most surprising improvement or presented most credibly (excerpt in Appendix E). The reflection diary highlighted that it came as a surprise that the appraised participants who received the most positive feedback, such as Choo and Ting, were not the most linguistically proficient participants. The resulting impact was an overall positive affect in class and participants who lacked confidence were surprised to be commended. Moreover, since the reflection diary observed that peer assessment correlated with teacher assessment, it could be inferred that the participants successfully mastered knowledge of what constituted multimodal oral presentation skills. The task design must ensure that participants are not competing against each other but collaborating towards a common goal. In Task 6, their common goal was to give positive encouragement to each other.

The findings indicated that the extent of Facebook's influence could very much depend on the participant's preference. Cindy insightfully suggested that some participants preferred to collaborate face-to-face while others preferred to share their views online. Evaluation in the reflection diary suggested that the sharing encouraged by Facebook was valuable to shy participants like Dee, who appreciated Facebook as a self-expression platform because she did not have to be pressured to speak in an impromptu manner like in the classroom. For Ting and her peers, collaborating through Facebook was so familiar and comfortable that they developed their speech outline through Facebook messaging without being instructed. For the more articulate participants like Mei, sharing with others on Facebook led to self-reflection: 'listening to others can help us to know what is our weakness and strength, what should improve and avoid during the presentation'. In summary, the analysis extended the significance of Web 2.0 for peer collaborations (Golonka et al., 2014) by indicating that participants who have low confidence and welcome peer sharing benefitted most extensively. 


\section{CONVEYED INDIVIDUALISED AND CONSISTENT TEACHER FEEDBACK}

In the interviews, participants expressed appreciation of the teacher feedback that was made more consistently available through Facebook through the pedagogical design. This is a valuable affordance of Facebook since the reflection diary drew attention to the fact that faceto-face classroom time was too limited to convey sufficient feedback. Table 3 presents an overview of the most popular functions played by teacher feedback and samples of each function.

TABLE 3. Functions of teacher feedback

\begin{tabular}{|c|c|}
\hline Functions & Samples from data \\
\hline Praising & $\begin{array}{l}\text { Timmy, you brought up a point that has not been taught in class: slide design } \\
\text { also involves the creative use of language. Good job! } \\
\text { Cindy, the depth and maturity of your comment is so impressive that I feel so } \\
\text { sad that the only thing holding you back is your English proficiency. Well done! }\end{array}$ \\
\hline $\begin{array}{l}\text { Extending the } \\
\text { participants' } \\
\text { comments }\end{array}$ & $\begin{array}{l}\text { Yes, better than listing in bullet points and takes an extra dose of creativity to } \\
\text { design this Minnie. } \\
\text { To walk while talking is sometimes a dramatic gesture to attract attention. }\end{array}$ \\
\hline $\begin{array}{l}\text { Probing with } \\
\text { questions }\end{array}$ & $\begin{array}{l}\text { Explain what improvements you made? } \\
\text { Do you think you could have used any of this for your presentation, Ting? }\end{array}$ \\
\hline Suggesting & $\begin{array}{l}\text { You should work on areas such as making eye contact with the audience and } \\
\text { using pauses with your voice when suitable. } \\
\text { Don't involve theory because of your audience. Focus on the practical } \\
\text { applications. }\end{array}$ \\
\hline Correcting & $\begin{array}{l}\text { Not 'increase alertness' but 'be more prepared'. } \\
\text { Your choice of words Amelie - not 'low condition', but 'dull'. }\end{array}$ \\
\hline
\end{tabular}

The teacher feedback that was scheduled and conveyed more consistently on Facebook could have supported the development of conceptual knowledge. To illustrate, in one instance (Task 3, Table 2), teacher feedback corrected the misconception that the font of the title in a PowerPoint slide cannot be similar to the content: 'I wouldn't call using the same font throughout a weakness since the size still helps to differentiate the two'. At times, participants required probing questions from the teacher before they could apply fundamental design principles. For example, Kai only examined the visual design of PowerPoint slides more analytically after the teacher asked this question: 'Does the chosen picture support the content?' (Task 4, Table 2).

In addition to developing knowledge in the principles of visual design of PowerPoint slides, Facebook allowed teacher feedback to enhance participants' self-awareness of themselves as presenters. The individualised feedback that was provided to one collaborative learning group on Facebook after the participants delivered their second oral presentation in class (Task 2, Table 2) could qualify this inference. The four members of this group were Hui, Timmy, Dee and Isaac. The teacher told Hui this: 'strong in the use of voice and gestures. But you need to work on the language accuracy'. For Timmy, the teacher wrote that 'Timmy is clever to draw our attention to the chart that sums up the content. His language accuracy is however his weakest area'. The teacher expressed that Dee 'needs to be very careful with her articulation. At times, I cannot understand what she is saying without looking at the slides. Be careful to avoid the phrase then next'. Finally, the teacher advised Isaac thus: 'please keep your confidence. Work on being more dramatic when appropriate and your language accuracy'. These findings demonstrate how the teacher could raise the awareness of students to the nonverbal elements of multimodal communication, as proposed by Camiciottoli and CampoyCubillo (2018). 
In contrast to previous studies which have validated how Web 2.0 extended the impact of peer feedback (Magogwe et al., 2015; Nadzrah et al., 2013), this study highlighted how teacher feedback that was more regular, immediate, and individualised through Facebook could improve conceptual knowledge of multimodal oral presentation skills and self-awareness.

\section{CONCLUSION}

Challenged by the lack of pedagogical approaches for multimodal oral presentation skills and intrigued by the potential of Web 2.0, we designed a pedagogical intervention (RMO2P) to respond to a practical need. The responsiveness of RMO2P lies in the teacher's proactive response in supporting the learning of students through engaging techniques which were available and agreeable to both the teacher and students. This paper aimed to explore the viability of integrating Facebook as a Web 2.0 tool with videos, collaborative learning and feedback to support the learning of multimodal oral presentation skills in an EAP class. Table 4 summarises the major findings while relating them to other studies.

TABLE 4. Summary of major findings

\begin{tabular}{|c|c|}
\hline Findings: & Relating to literature: \\
\hline $\begin{array}{l}\text { 1)Facebook was a feasible tool in terms of the } \\
\text { convenience it provides for the management of } \\
\text { multimodal learning tasks and comfort levels that } \\
\text { embolden participants to express critical } \\
\text { thoughts. }\end{array}$ & $\begin{array}{l}\text { Reinforced the suggestion that multimodal tasks could } \\
\text { enhance student engagement (Cope \& Kalantzis, 2015) } \\
\text { Contradicted reports of student inhibition towards } \\
\text { engaging Facebook for formal learning (Sun \& Yang, } \\
\text { 2015) }\end{array}$ \\
\hline $\begin{array}{l}\text { 2)Through effective integration with videos, } \\
\text { participants increased conceptual knowledge } \\
\text { because Facebook was conducive for the } \\
\text { extension of the range of model presentations, } \\
\text { peer sharing, expression of views and validation } \\
\text { of interests. This impact included students who } \\
\text { were weak in linguistic proficiency. }\end{array}$ & $\begin{array}{l}\text { The study demonstrated how meaningful learning } \\
\text { experiences could be created through engaging Facebook } \\
\text { (Kabilan et al., 2010) } \\
\text { Reinforced the proposal that multimodal features could } \\
\text { enhance student engagement (Cope \& Kalantzis, 2015) }\end{array}$ \\
\hline $\begin{array}{l}\text { 3)Participants enhanced conceptual knowledge } \\
\text { and affect because Facebook enabled peer } \\
\text { sharing and peer support. Students who have low } \\
\text { confidence and favour peer sharing could benefit } \\
\text { more. }\end{array}$ & $\begin{array}{l}\text { Concurred with previous studies that suggested Web } 2.0 \\
\text { supported collaboration (Chawinga, 2017; Golonka et al., } \\
\text { 2014) }\end{array}$ \\
\hline $\begin{array}{l}\text { 4)Facebook supported the provision of teacher } \\
\text { feedback to be consistent and individualised. } \\
\text { Conceptual knowledge, especially in visual } \\
\text { design, and self-awareness increased. }\end{array}$ & $\begin{array}{l}\text { While previous studies mostly focused on peer feedback } \\
\text { (Nadzrah et al., 2013), the findings demonstrated how } \\
\text { teacher feedback could be effectively incorporated with a } \\
\text { Web } 2.0 \text { tool } \\
\text { Responded to suggestions to raise the awareness of } \\
\text { students to the non-verbal elements of multimodal } \\
\text { communication (Camiciottoli \& Campoy-Cubillo, 2018) }\end{array}$ \\
\hline
\end{tabular}

Past studies that linked Web 2.0 to the learning of various types of oral skills only considered the impact of Web 2.0 singularly (Huang, 2015; Magogwe et al., 2015; Shih, 2010; Sun \& Yang, 2015), but this study specifically targeted multimodal oral presentation skills and clearly demonstrated that as a Web 2.0 tool, Facebook effectively integrated with other pedagogical techniques due to its multimodal affordances and social networking features which assisted peer sharing and teacher feedback. The learning gains, however, could only be linked to conceptual knowledge and self-awareness. Moreover, the analysis affirmed the need for purposeful design of tasks that engages multimodality (Cope \& Kalantzis, 2015) and could be integrated with other techniques. We propose for the choice of Web 2.0 tool to be relevant and respectful to the teacher and the students' literacy landscape and preferences. At the time of 
study, the teachers and students were tolerating a limited LMS and student indicated preference for Facebook as an alternative tool to support learning.

The natural setting, which we had no control over and accommodated only 20 students and one teacher-researcher, limited the generalisability of the study. Nonetheless, it is hoped that the naturalistic description of vicarious experience featured a heuristic which could illustrate how teachers could explore and develop alternative pedagogical methods. For instance, after data collection and data analysis of this study, the teacher-researcher experimented with adapting the Facebook tasks for an institution with a more efficient LMS system to enhance student engagement and provide consistent feedback. Thus, we hope that even practitioners who have an efficient LMS system to support them and who are curious to explore other Web 2.0 tools could adapt the Facebook tasks described in this paper. Finally, although the findings were based on a small study, we believe that the insights gained are significant for developing pedagogical methods that target multimodal oral presentation skills (Barrett and Liu, 2016) and extending the budding research on Facebook as a learning environment for language pedagogy (Barrot, 2018). After all, more research with different pedagogical suggestions could address different learner needs in oral presentations (Tsang, 2020).

\section{ACKNOWLEDGEMENT}

This work was supported by the FRGS grant R/FRGS/A0400/01380A/002/2019/00718 awarded by Ministry of Higher Education Malaysia.

\section{REFERENCES}

Abusalim, N., Rayyan, M., Jarrah, M., \& Sharab, M. (2020). Institutional adoption of blended learning on a budget. International Journal of Educational Management, 34(7), 12031220.

Adi Kasuma, S.A. (2017). Four characteristics of Facebook activities for English language learning: A study of Malaysian university students' needs and preferences. Advances in Language and Literary Studies, 8(3), 155-171.

Anstey, M., \& Bull, G. (2018). Foundations of multiliteracies reading, writing and talking in the 21st Century. London: Routledge.

Arzu, E. (2014). Facebook groups as a supporting tool for language classrooms. Turkish Online Journal of Distance Education, 15(3), 18-26.

Barrett, N.E., \& Liu, G.Z. (2016). Global trends and research aims for English academic oral presentations: Changes, challenges, and opportunities for learning technology. Review of Educational Research, 20(10), 1-45.

Barrot, J. (2018). Facebook as a learning environment for language teaching and learning: A critical analysis of the literature from 2010 to 2017. Journal of Computer Assisted Learning, 34(6), 863-875.

Braun, V., \& Clarke, V. (2006). Using thematic analysis in psychology. Qualitative Research in Psychology, 3(2), 77-101.

Camiciottoli, B.C., \& Campoy-Cubillo, M.C. (2018). Introduction: The nexus of multimodality, multimodal literacy, and English language teaching in research and practice in higher education settings. System, 77, 1-9.

Chawinga, W.D. (2017). Taking social media to a university classroom: Teaching and learning using Twitter and blogs. International Journal of Educational Technology in Higher Education, 14(3), 1-19. 
Cope, B., \& Kalantzis, M. (2015). The things you do to know: An introduction to the pedagogy of multiliteracies. In B. Cope \& M. Kalantzis (Eds). A pedagogy of multiliteracies: Learning by design (pp. 1-36). London: Palgrave.

Council of Europe. (2018). Common European framework of reference for Languages: Learning, teaching, assessment. Companion volume with new descriptors. Cambridge: Cambridge University Press.

De Grez, L. (2009). Optimizing the instructional environment to learn presentation skills (Dissertation). Universiteit Gent, Ghent, Belgium.

De Grez, L., Valcke, M., \& Roozen, I. (2009). The impact of an innovative instructional intervention on the acquisition of oral presentation skills in higher education. Computers and Education, 53, 112-120.

Golonka, E.M., Bowles, A.R., Frank, V.M., Richardson, D.L., \& Freynik, S. (2014). Technologies for foreign language learning: A review of technology types and their effectiveness. Computer Assisted Language Learning, 27(1), 70-105.

Hayward, P.A. (2017). Incorporating TED Talk assignments into a public-speaking course. Communication Teacher, 31(4), 239-244.

Hendricks, C. (2017). Improving schools through action research: A reflective practice approach $\left(4^{\text {th }}\right.$ ed.). USA: Pearson Education, Inc.

Henning, J.E., Stone, J.M., \& Kelly, J.L. (2009). Using action research to improve instruction: An interactive guide for teachers. New York: Taylor and Francis.

Huang, H.C. (2015). From web-based readers to voice bloggers: EFL learners' perspectives. Computer Assisted Language Learning, 28(2), 145-170.

Hung, H.T., Chiu, Y. C. J., \&Yeh, H. C. (2013). Multimodal assessment of and for learning: A theory-driven design rubric. British Journal of Educational Technology, 44, 400-409.

Kabilan, M.K., Norlida, A., \& Mohd Jafre, Z.A. (2010). Facebook: An online environment for learning of English in institutions of higher education? Internet and Higher Education, 13, 179-187.

Kress, G. (2010). Multimodality: A social semiotic approach to contemporary communication. London \& New York: Taylor \& Francis.

Li, A.Y. (2017). Dramatic declines in higher education appropriations: State conditions for budget punctuations. Research in Higher Education, 58, 395-429.

Lim, F.V., Towndrow, P.A., \& Tan, J.M. (2021). Unpacking the teachers' multimodal pedagogies in the primary English language classroom in Singapore. RELC Journal, 1 -15 .

Magogwe, J.M., Ntreke, B., \& Phetlhe, K.R. (2015). Facebook and classroom group work: A trial study involving University of Botswana advanced oral presentation students. British Journal of Educational Technology, 46(6), 1312-1323.

Manca, S., \& Ranieri, M. (2016). Is Facebook still a suitable technology-enhanced learning environment? An update critical review of the literature from 2012 to 2015. Journal of Computer Assisted Learning, 32(6), 503-528.

Marshall, C., \& Rossman, G.B. (2011). Designing qualitative research (5 ${ }^{\text {th }}$ ed.). USA: SAGE Publications.

McNiff, J., \& Whitehead, J. (2011). All you need to know about action research ( $2^{\text {nd }}$ ed.). Great Britain: Sage Publications.

Mills, K.A. (2016). Literacy theories for the digital age: Social, critical, multimodal, spatial, material and sensory lenses. UK: Multilingual Matters.

Nadzrah, A.B., Hafizah, L., \& Afendi, H. (2013). Enhancing ESL learners speaking skil through asynchronous online discussion forum. Asian Social Science, 9(9), 224-233.

Naghdipour, B. (2017). 'Close your book and open your Facebook': A case for extending classroom collaborative activities online. The Journal of AsiaTEFL, 14(1), 130-143. 
Nguyen, M.H. (2013). EFL students' reflections on peer scaffolding in making a collaborative oral presentation. English Language Teaching, 6(4), 64-73.

O'Halloran, K.L., Tan, S., \& Smith, B.A. (2016). Multimodal approaches to English for academic purposes. In K. Hyland, \& P. Shaw (Eds.), The Routledge handbook of English for academic purposes (pp. 256 - 269). London \& New York: Routledge.

Patton, M.Q. (2015). Qualitative research and evaluation methods (4 ${ }^{\text {th }}$ ed.). USA: SAGE Publications.

Ponnudurai, P., \& Jacob, T.T. (2014). Facebook: A shift from social to academia. ProcediaSocial and Behavioral Sciences, 123, 122-129.

Rasiah, R. (2014). Transformative higher education teaching and learning: Using social media in a team-based learning environment. Procedia - Social and Behavioral Sciences, 123, 369-379.

Reyna, J., Hanham, J., \& Meier, P. C. (2018). A framework for digital media literacies for teaching and learning in higher education. E-Learning and Digital Media, 15(4), 176190. https://doi.org/10.1177\%2F2042753018784952

Saldaña, J. (2016). The coding manual for qualitative researchers (3rd ed.). USA: Sage.

Shih, R.C. (2013). Effect of using Facebook to assist English for Business Communication course instruction. TOJET: The Turkish Online Journal of Educational Technology, $12(1), 52-59$.

Shih, R.C. (2010). Blended learning using video-based blogs: Public speaking for English as a second language students. Australian Journal of Educational Technology, 26(6), 883897.

Statista. (2021). Number of Facebook users in Malaysia from 2017 to 2025 (in millions). https://www.statista.com/forecasts/1136333/facebook-users-in-malaysia

Sun, Y,C., \& Yang, F.Y. (2015). I help, therefore, I learn: Service learning on Web 2.0 in an EFL speaking class. Computer Assisted Language Learning, 28(3), 202-219.

Tracy, S.J. (2013). Qualitative research methods: Collecting evidence, crafting analysis, communicating impact. Hoboken, NJ: Wiley-Blackwell.

Tsang, A. (2020). Enhancing learner's awareness of oral presentation (delivery) skills in the context of self-regulated learning. Active Learning in Higher Education, 21(1), 39-50.

Unsworth, L., \& Mills, K.A. (2020). English language teaching of attitude and emotion in digital multimodal composition. Journal of Second Language Writing, 47, 1-17.

Van Ginkel, S., Gulikers, J., Biemans, H., \& Mulder, M. (2015). Towards a set of design principles for developing oral presentation competence: A synthesis of research in higher education. Educational Research Review, 14, 62-80.

Van Ginkel S., Gulikers, J., Biemans, H., \& Mulder, M. (2017). The impact of the feedback source on developing oral presentation competence. Studies in Higher Education, 42(9), 1671-1685. 


\section{APPENDIX A}

\section{PROFILING QUESTIONNAIRE}

1. Year of birth:

2. SPM Grade for English:

3. Which languages do you speak? Circle the relevant response.

English

Malay

Mandarin

Others (Please state:

4. Do you own a Facebook account?

Yes / No (Circle the relevant response)

5. How often do you log on your Facebook account? Circle the relevant response.

Once a day

Once every few days

Once a week

None of the above (Please state:

6. What do you use Facebook for? Circle the relevant response.

View and/or share pictures

View and/or share music

View and/or share videos

View and/or share articles

View and/or share opinions

Connect with people

Extend academic learning

Others (Please state:

7. Are you interested to use Facebook for formal learning in class?

Yes / No (Circle the relevant response)

8. Are you concerned with your privacy if Facebook is used for formal learning in class? Yes / No (Circle the relevant response) 


\section{APPENDIX B}

\section{SAMPLE OF REFLECTION DIARY WITH FIELD NOTES}

\begin{tabular}{|c|c|c|}
\hline Act & Evaluate & Modify \\
\hline $\begin{array}{l}\text { Facebook task } \\
\text { Week } 7 \\
\text { Each student posted a TED video } \\
\text { of his/ her own choice and } \\
\text { provided an analysis This activity } \\
\text { continued until Week } 12 \text {. } \\
\text { I engaged them in a dialogue } \\
\text { whenever possible to provide } \\
\text { feedback. }\end{array}$ & $\begin{array}{l}\text { Student responses reflected a variety of } \\
\text { interests and personal preferences of } \\
\text { styles and subject matters. There were } \\
\text { interests in serious talks, humorous talks } \\
\text { and talks involving sophisticated use of } \\
\text { technological aids. Although many } \\
\text { students did choose a presentation } \\
\text { related to technology as expected, I } \\
\text { never expected them to be interested in } \\
\text { subject matters such as psychology, } \\
\text { science, education, history, music, } \\
\text { design and art. This activity provided a } \\
\text { platform to demonstrate their interests } \\
\text { and drew insightful comments from the } \\
\text { more reticent students. The focus of } \\
\text { feedback was more on the fluency and } \\
\text { development of comments instead of } \\
\text { language accuracy to encourage } \\
\text { students' expressions of thoughts. }\end{array}$ & $\begin{array}{l}\text { Continue this activity for } \\
\text { next semester. } \\
\text { Consider utilising some } \\
\text { presentations highlighted by } \\
\text { students for future classes. }\end{array}$ \\
\hline
\end{tabular}




\section{APPENDIX C}

\section{FOCUS GROUP INTERVIEW QUESTIONS}

\begin{tabular}{|c|c|}
\hline Questions & Probes \\
\hline $\begin{array}{l}\text { 1) How do you feel about the public speaking } \\
\text { course that just ended? }\end{array}$ & $\begin{array}{l}\text { - Do you like how the course was taught? } \\
\text { - Is there anything that you don't like? } \\
\text { - How about you, [name]? }\end{array}$ \\
\hline $\begin{array}{l}\text { 2) What do you think about the use of videos } \\
\text { through Facebook used in this course? }\end{array}$ & $\begin{array}{l}\text { Tell me how you feel about the videos } \\
\text { used in class. } \\
\text { - What do you think of the selection of } \\
\text { videos? } \\
\text { - Did you have any problem with the } \\
\text { videos? } \\
\text { - If the videos have helped you, how have } \\
\text { they helped? } \\
\text { - Do you have any suggestion for future } \\
\text { use? }\end{array}$ \\
\hline $\begin{array}{l}\text { 3) How do you feel about the use of Facebook to } \\
\text { help you learn? }\end{array}$ & $\begin{array}{l}\text { Do you like to use Facebook to learn } \\
\text { speaking? } \\
\text { - Did you have any problem with the use? } \\
\text { Do you have any suggestion for future } \\
\text { use of Facebook? }\end{array}$ \\
\hline $\begin{array}{l}\text { 4) How do you think this course can be improved } \\
\text { to help you learn? }\end{array}$ & $\begin{array}{l}\text { - Is there anything that you wanted to } \\
\text { learn but was not covered in this course? } \\
\text { - What else do you think the teacher can } \\
\text { do for the students? }\end{array}$ \\
\hline
\end{tabular}




\section{APPENDIX D}

\section{EXCERPT OF FACEBOOK TASK 5}

\section{Ang}

Strengths: Simon Sinek is an awesome speaker. He has performed his idea uniquely by drawing a "split" graph on a white board instead of using visual aids like PPT which is very in common. He has well control on his tone; he emphasized phrases by slowing down and repeating it throughout the speech; his interesting body languages works well with the rhythm of his speech (there's hand movements while he mentioned about examples which related to Steve Jobs, Michael Dell and etc) and the play of act (which is about an experiment) even helps out in further explaining his idea. He also enhanced his presentation by making fabulous interactions with the audience (besides of having eye contacts, he also shared/mentioned quite a lot of examples which audience most likely to resonate with, such as the babysitter one). Weaknesses: Actually I think Simon Sinek is beyond perfect (of course, that is my own perception), so if I'm gonna nitpick, then his outfit will be the one I'll criticise on. He didn't stand out with the grey jacket and looked "dull" when he stood in front of the black background, maybe he can try to take off the grey jacket, just keep to the pink shirt.
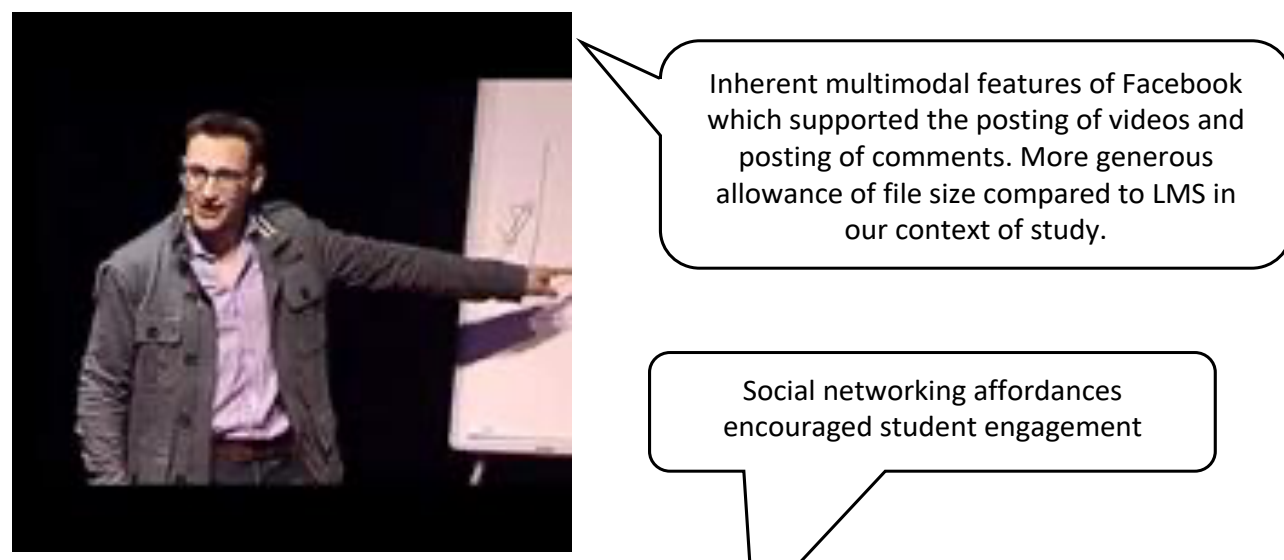

Teacher: Detailed observations Ang! This is definitely worth talking about!

Ang: I Like him so much... The other talk by Simon Sinek, which is about the Golden Circle is also very nice, very inspiring 


\section{APPENDIX E}

\section{EXCERPT OF FACEBOOK TASK 6}

Teacher:

Help me give a fair assessment. Comment if you feel a student

Has improved the most/

Is most surprising/

Is most informative/

Presents self credibly

As long as $u$ have something good to say, say it here. Grab the chance to make a difference!

Yee: $\quad$ Choo, because last time, it was hard for her to speak smoothly, but yesterday she spoke well and smoothly

Ketam: $\quad$ Ting... because this time she take all her time to share with us about their topic, and although her voice is trembling but she still make me feel that she was confident.

Mei: $\quad$ Choo, she speaks smoothly and fluently in this presentation, she is very confident and it really shocked and surprised me

Carrie: $\quad$ Ang $\sim$ she speak very well and totally took part to accomplish her group presentation like appearing in her own video ...

Minnie: $\quad i$ think is Ting too.. although she didn't speak smoothly and trembling in her voice, she managed to get our attention and it can be seen clearly that she is well-prepared

Ang: $\quad$ Actually, I think Timmy, Dee and Choo improved a lot loh... Pls don't make me choose among them I love three of them sooooooooooo much...

Ting: $\quad$ I think Cindy and Choo have improved a lot because both of them are speak more fluently this time compare with their previous presentation.

Dee: $\quad$ Choo speak smoothly than before.. and Ting have presents herself credibly, she let me feel she is very clear with her topic, this make me admire her..both of them have improve in this presentation..

Cindy: Ting, she knows her part very well!

Choo: I think Ting improved a lot, she explain very clear and i understand what she wants to express $\sim$ 


\section{ABOUT THE AUTHORS}

Lee Sze Seau (Ph.D) is passionate about implementing technology-related classroom initiatives to engage and enhance learning. She believes that teachers can spearhead the desired changes in the education system. Dr Lee is currently a lecturer in the Education department in UCSI University, Kuala Lumpur.

Hazita Azman (Ph.D) is Professor of Applied Linguistics and Literacy in ESL. She has researched and published on ESL teaching methodology, rural literacy, and multimodal literacies. Her research projects on digital literacies have received gold medals and copyrights for ESL digital literacy and rural e-Literacy at the national level. 